\title{
Population structure and accompanying biota of the snail Turbo (Callopoma) funiculosus (Gastropoda: Turbinidae), on Socorro Island, Revillagigedo Archipelago, Mexico
}

\author{
Oscar E. Holguin Quiñones ${ }^{1}$ \& Jesús E. Michel-Morfín ${ }^{2}$ \\ 1 Centro Interdisciplinario de Ciencias Marinas-IPN. A.P. 592, La Paz, B.C.S., CP 23096, México. Fax: (612) 12253 \\ 22; oholguin@ipn.mx \\ 2 Departamento de Estudios para el desarrollo sustentable de zonas costeras. Universidad de Guadalajara. Gómez Farias \\ 82, San Patricio-Melaque, Jal. C.P. 48980, México. Fax (315) 355-6331; michel@costera.melaque.udg.mx
}

Received 10-VI-2002. C Corrected 13-I-2004. Accepted 29-V-2006.

\begin{abstract}
The porcelain snail, Turbo funiculosus, is a potential fishery resource that almost has not been studied or used commercially. In March of 1992, we sampled T. funiculosus in Bahía Binners and Bahía Blanca, Socorro Island, Revillagigedo Archipelago, using $25 \mathrm{~m}^{2}$ quadrants. We found that total length varies between 3.0 and $85 \mathrm{~mm}$, proportional weight between 3.0 and $228 \mathrm{~g}$, and density between 6.21 and $9.87 \mathrm{ind} / \mathrm{m}^{2}$. The largest organisms (over $50 \mathrm{~mm}$ ) contain $30.6 \%$ of soft parts. Porcelain snail populations remain unexploited on Revillagedo Archipelago and could be a potential resource under an adequate management strategy. Rev. Biol. Trop. 54 (4): 1079-1084. Epub 2006 Dec. 15.
\end{abstract}

Key words: Turbo funiculosus, mollusk, density, weight, length, Socorro Island.

Among the marine invertebrates, mollusks are one of the most important groups on Socorro Island. Turban shells are benthic marine animals, fairly common on the Revillagigedo Islands, which can also be found in tidal pools, shallow rocky bottoms, and weed-covered reefs. They are members of the order Archeogastropoda, family Turbinidae. They are primitive prosobranchs with radula modified for herbivory (Brusca and Brusca 1990) and possess a single snail-like shell. They also possess a thick operculum, a calcareous plate used to protect the animal when it withdraws into its shell.

The porcelain snail, or turban shell Turbo funiculosus, stands out because of its abundance and its possible integral uses in this insular place. This is also true of the indopacific species $T$. marmoratus and T. brunneus (Devaraj 1996, Castell and Sweatman 1997, Dorairaj and Soundararajan 1998, Kikutani et al. 2002), the foot and shell of which have a high market value. Other internal parts are also used as food for domestic animals. The foot is actually utilized in Socorro Island only in subsistence fisheries. It is still an important resource since it has not been fished commercially (Holguin 1991). Keen (1971) states that this species is widely distributed on the islands of the Revillagigedo Archipelago. He also mentions that it can be found, though less frequently, in the area of Cape San Lucas B.C.S.

The faraway location of the Revillagigedo Archipelago from the continental coasts had been one of the factors that has made it difficult to complete any scientific study. The biological or ecological aspects of the population of $T$. funiculosus were not studied by researchers. The state of the populations of this mollusk is practically unknown in its area of geographical distribution. Knowledge of this species on Socorro Island is limited to the 
references made by Strong and Hanna 1930 (as T. fluctuosum), Keen 1971, Chan 1974, Holguin 1991, Holguín et al. 1992, Bautista-Romero et al. 1994, Holguin 1994, Mille-Pagaza et al. 1994, Emerson 1995, and Reyes-Bonilla 1999. Nonetheless, these works do not address any aspects of its biology, fishery, or population status. Chan (1974) made 36 dives at depths between 3 and $23 \mathrm{~m}$ in Bahía Braithwaite and found the species at approximately 15 fathoms. There is no additional information in the literature about the abundance and distribution of this species.

Many species coexist with overlapping ranges and food resources. Very few reports exist about the fauna that accompanies T. funiculosus (Bautista-Romero et al. 1994, Holguin 1994, Mille-Pagaza et al. 1994). Numerous species of algae, invertebrates, and fish occupy the intertidal and splash zones with partial overlapping ranges. A typical rocky shore setting might show the sequence Littorinidae, Acmaeidae, Mytilidae, Ostreidae, Turbo, chitons, and Trochidae as the most conspicuous forms of mollusks from the splash zone (Engeman and Hegner 1981).

\section{MATERIALS AND METHODS}

The Revillagigedo Archipelago (Fig. 1) is located approximately $350-650 \mathrm{~km}$ southeast of the Baja California Peninsula, $580 \mathrm{~km}$ west of the Colima coast (Llinas-Gutierrez et al. 1993), and is comprised of Socorro, Clarion, San Benedicto, and Roca Partida islands. Socorro Island, with a surface area of $167 \mathrm{~km}^{2}$, is the largest of the islands and has a maximum diameter of $16 \mathrm{~km}$ in a NW-SW direction. Geographically, Socorro Island is located at $18^{\circ} 41^{\prime} 57^{\prime \prime} \mathrm{N}$ and $110^{\circ} 56^{\prime} 33^{\prime \prime} \mathrm{W}$ (Troyo-Diéguez and Pedrín 1994). The island is composed primarily of braced igneous rock, with the presence of smooth stones and sandy or stone-sandy beaches (Holguin 1994).

In March of 1992, some observations about the densities by area were done. They determined the relationship between size and weight of $T$. funiculosus in two locations of the island: Bahía Binners in the southern part and Bahía Blanca NW (or Playa Blanca) located in the northeast of the same island (Fig. 1).

The data was obtained out of a total of eight quadrants, which were made using a $20 \mathrm{~m}$ cord marked every $5 \mathrm{~m}$. The squares were $5 \mathrm{x}$ $5 \mathrm{~m}$ with an area of $25 \mathrm{~m}^{2}$ each. The data about the relative abundance or density of the organisms is the result of the counting and gathering of all the live shells found in the eight quadrants (200 $\mathrm{m}^{2}$ in total), situated in tide pools and rocky areas of the intertidal fringe.

The sampled specimens in only one quadrant by location were used to elaborate histograms of size frequency. In Bahía Blanca a small lot of 50 individuals was taken to get information of the proportion of the weight of the viscera and the weight of the foot respective to the total weight. The register of the size parameter was done using a $0.5 \mathrm{~mm}$ accuracy vernier calliper, considering the height or major dimension along the columellar axis. The total weight (including the shell) was taken by a $0.5 \mathrm{~g}$ accuracy triple arm scale. After being measured, all animals were liberated in the rocky intertidal zone.

The analysis of the weight and sizes was carried out using the computer program Stat

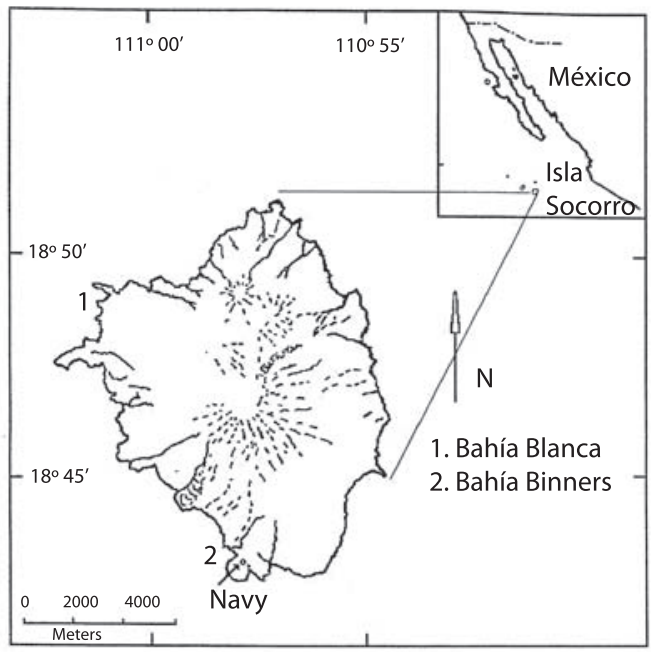

Fig. 1. Sampling sites on Socorro Island, Revillagigedo, March 1992. 
Graphic 3.0 and a multiplying model of simple regression: $\mathrm{Y}=\mathrm{ax}$ for size weight correlation, obtaining regressions by sampling areas.

\section{RESULTS}

In comparison to other zones that presented a high degree of difficulty and risk, the relative ease of disembarking at the two stations distant from one another made sampling possible. The basaltic coast exposed to continuous wave action is populated by $T$. funiculosus in the rocky intertidal zone and tide pools, as well as in the upper subtidal zone. It was observed that the small sizes have a gregarious distribution and it is well known that the juveniles (under $25 \mathrm{~mm}$ ) are located in groups, usually in quiet tide pools, protected areas, between rocks and stones, or in those areas which are not very exposed to wave action. On the contrary, adults of bigger sizes live well dispersed and inhabit turbulent waters at midlittoral fringe to 15 fathoms of depth (Chan 1994). Shallow areas, such as tide pools with abundant small rubble, may represent good conditions for individuals of $<25 \mathrm{~mm}$, but rocky coasts exposed to waves and deeper areas with larger rocks are better for individuals of greater than $25 \mathrm{~mm}$.

The porcelain shells feed predominantly on macro and microalgae, which they scrape with their radula. In the sampling locations, the tide wells and propitious areas for their development are frequently found. These gastropods interact in such an environment with numerous species of algae, invertebrates, and fish. Turbo shells, especially the smallest, are part of the diet of the sea crown of thorn stars Acanthaster planci (Holguin et al. 1992), and of predator gastropods: Conus tiaratus, Thais planospira, T. speciosa, Plicopurpura pansa, the cephalopod Octopus bimaculatus (Holguin 1994) and the fishes Melichtys niger, Calotomus spinidens and Diodon hystrix, among others (Bautista-Romero et al. 1994), all of which share their habitat.

Among the frequently found invertebrates which accompany the Turbo shell are the mollusks Barbatia bailyi, Isognomon janus, Chama squamuligera, Littorina spp., Nerita spp., Cerithium maculosum, Petaloconchus complicatus, Columbella socorroensis, Mitrella baccata, Hipponix pilosus, H. panamensis, C. tiaratus, Chiton articulatus and $O$. bimaculatus, the echinoderms Echinometra vanbruntii, E. oblonga, Tripneustes depressus and Toxopneustes roseus, the crustaceans Pachygrapsus transversus, Calcinus explorator, Petrolistes spp. and Ozius spp., among others. The algae which accompany the Turbo shell are Enteromorpha flexuosa, Chaetomorpha gracilis, Caulerpa racemosa, Dictyota dichotoma, Hypnea cervicornis, Amphiroa spp., Jania capillacea, Ceramium gracillillum, Centroceras clavulatum, Herposiphonia tenella and Laurencia spp. (Holguin 1994).

Information about relative densities of the accompanying fauna was obtained. The density data obtained in the study of benthic communities in March 1992 on Socorro Island is given in a genera level comparison (Table 1).

The high density of the turban shell population in the intertidal fringe is due, among

TABLE 1

Relative densities of the accompanying invertebrate fauna associated with $\mathrm{T}$. funiculosus on Isla Socorro, Revillagigedo

\begin{tabular}{lcc}
\multicolumn{1}{c}{ Species } & $\begin{array}{c}\text { Location } \\
\text { Bahía Binners } \\
\text { Orgs } / \mathrm{m}^{2}\end{array}$ & $\begin{array}{c}\text { Orgsía Blanca } \\
\text { O }\end{array}$ \\
Turbo funiculosus & 4.7 & 15.1 \\
Thais speciosa & 0.22 & 0.1 \\
Cerithium maculosum & 0.11 & - \\
Petaloconchus complicatus & 20.5 & 0.6 \\
Hipponix pilosus & 2.0 & 33.0 \\
Plicopurpura pansa & 0.27 & 0.18 \\
Isognomon janus & 9.1 & 16.4 \\
Chiton articulatus & 3.72 & - \\
Echinometra vanbruntii & 1.22 & - \\
Tripneustes depressus & 0.33 & - \\
Calcinus explorator & 4.0 & 2.1 \\
Pachigrapsus transversus & 3.55 & 0.93
\end{tabular}


other reasons, to the elevated availability of food, the stable conditions of the environment, and the moderated effect of certain predators in this level. For the month of March, the counting by quadrant of turbo shell in two locations gave the next density values, with the size and weight intervals shown in Table 2.

Size frequency for both locations shows the separation of groups. In Bahía Binners (Fig.
2) groupings of individuals of 3 and $24 \mathrm{~mm}$ and others of 24 and 54 were found. In Bahía Blanca (Fig. 3). We observed three groups: 16 to 32,32 to 56 , and 56 to $85 \mathrm{~mm}$.

T. funiculosus is very well represented in all the series of sizes in the midlittoral, fluctuating between 3.0 and $85 \mathrm{~mm}$ of length (Fig. 2, 3) and the proportional weight varies between 3.0 and 228 g. The Fig. 4 and 5 show

TABLE 2

Density values and size and weight intervals

$\begin{array}{lcccccc}\text { Location } & \begin{array}{c}\text { Area } \\ \mathrm{m}^{2}\end{array} & \begin{array}{c}\text { Total } \\ \text { Number }\end{array} & \begin{array}{c}\text { Average } \\ \text { orgs } / \mathrm{m}^{2}\end{array} & \begin{array}{c}\text { Max. Density } \\ \text { orgs } / \mathrm{m}^{2}\end{array} & \begin{array}{c}\text { Length } \\ \mathrm{mm}\end{array} & \begin{array}{c}\text { Weight } \\ \mathrm{g}\end{array} \\ \text { Bahía Binners } & 100 & 621 & 6.21 & 14 & 5-55 & 0.3-70 \\ \text { Bahía Blanca } & 100 & 987 & 9.87 & 19 & 12-85 & 0.5-228\end{array}$

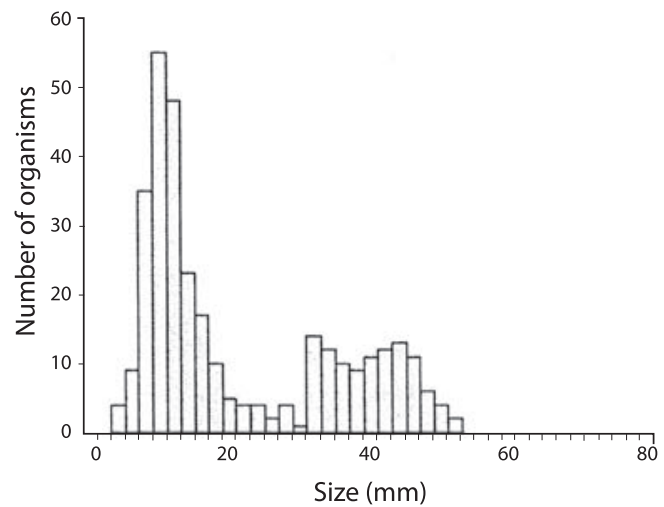

Fig. 2. Size frequencies of T. funiculosus on Bahia Binners, March 1992.

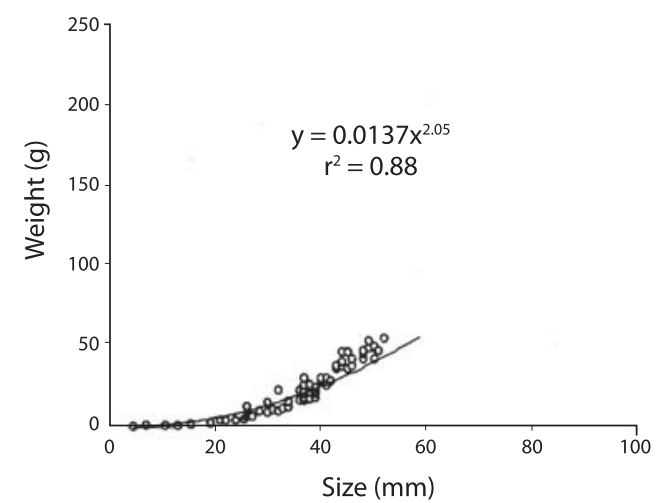

Fig. 4. Regression of size-weight for T. funiculosus on Bahia Binners, March 1992.

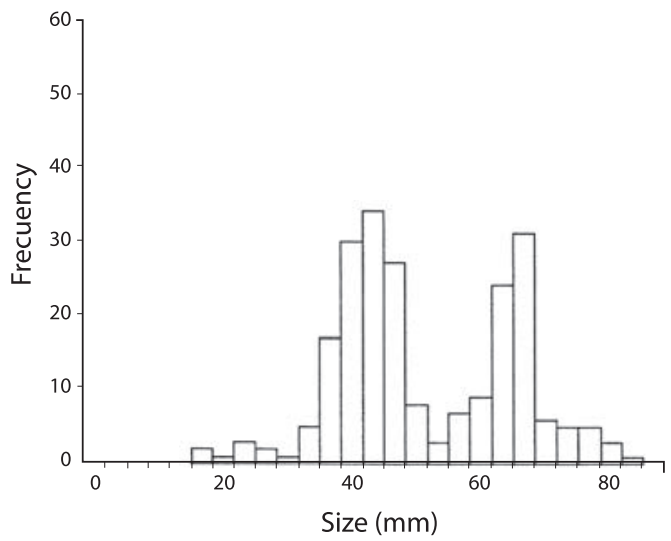

Fig. 3. Size frequencies of T. funiculosus on Bahia Blanca, March 1992.

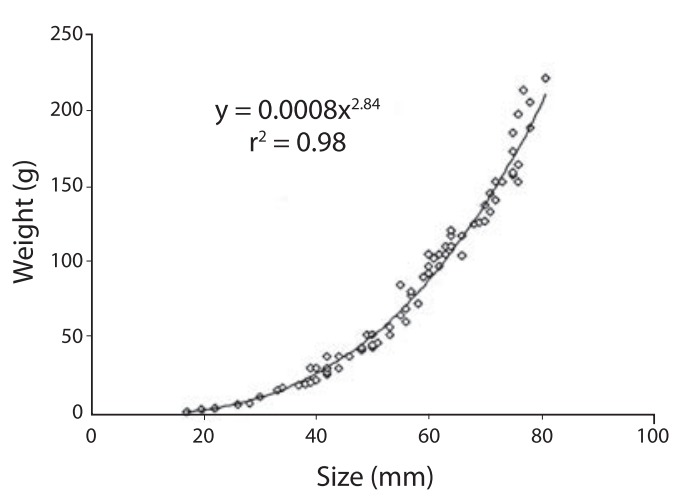

Fig. 5. Regression of size-weight for T. funiculosus on Bahia Blanca, March 1992. 
the regression of size-weight found in two concentrations of living organisms, belonging to the two study locations.

The relation of weight in the soft parts in sizes bigger than $50 \mathrm{~mm}$ is $30.6 \%$ of the total weight of the living organism, $7.44 \%$ corresponds to the foot or callus, and $23.16 \%$ to the viscera. These proportions were not previously reported in the literature for this species.

\section{DISCUSSION}

As a result of the observation of the coastal strip of the superior midlittoral and the infralittoral parts of Socorro Island, the abundance of T. funiculosus was determined. The densities of some important species that occupy the same area were also determined. The turban shell is abundant on Socorro Island and has an elevated commercial value because of its meat and its shell. Various accompanying species like P. pansa (Michel-Morfín et al. 2002) and C. articulatus (Holguin and Michel-Morfín 2002), have commercial value and represent potential resources on Socorro Island.

It is evident in the location of Bahía Binners that the sizes larger than $40 \mathrm{~mm}$ are less represented. On the contrary, in the samplings of Bahía Blanca they are predominant. This is due to the fact that the first location is very close and very accessible to an island village (naval sector), which in the year 1992, before an Everman Volcano eruption, had an average population of 150 people. This caused the extraction for food consumption of the major sizes in the intertidal zone (this is possible to verify observing the shells left on the beach). On the other side, Bahía Blanca is very far from any populated zone and it is not accessible by land, which is why the population structure of the Turbo shell in this location remains unaltered.

Some parts of the island are inaccessible by land and barely accessible by sea. For that reason the population of this species remains unaltered by exploitation and its harvesting could be only possible under strict measures of protection and under an adequate management plan. However, new population studies are required in order to know some aspects about population dynamics, like growth, mortality, recruitment and reproduction, beside new population abundance estimations around all island rocky shores are important.

\section{ACKNOWLEDGMENTS}

We are grateful to the Dirección de Estudios de Posgrado e Investigación del Instituto Politécnico Nacional and Consejo Nacional de Ciencia y Tecnología for funding this work. Thanks to the Comisión de Operación y Fomento de Actividades Académicas. Thanks to Silvia Mille P., Alicia Pérez and Ma. de Jesús Parra for their help with the field work, and Ma. Consuelo González and Bryan Keagle for the help on the English manuscript.

\section{RESUMEN}

El caracol porcelana, Turbo funiculosus, es un recurso pesquero potencial que casi no ha sido estudiado ni se ha utilizado comercialmente. En marzo de 1992, se realizó un muestreo de $T$. funiculosus en Bahía Binners y Bahía Blanca, isla Socorro, archipiélago Revillagigedo, empleando cuadrantes de $25 \mathrm{~m}^{2}$. Se encontraron variaciones en la longitud total entre 3.0 y $85 \mathrm{~mm}$, el peso proporcional entre 3.0 y 228 g, y la densidad entre 6.21 y $9.87 \mathrm{ind} / \mathrm{m}^{2}$. Los organismos de mayor tamaño (más de $50 \mathrm{~mm}$ ) contienen $30.6 \%$ de partes suaves. Las poblaciones del caracol porcelana siguen siendo inexplotadas en el archipiélago Revillagedo y podrían ser un recurso potencial de la industria pesquera bajo un adecuado plan de manejo.

Palabras clave: Turbo funiculosus, molusco, densidad, peso, longitud, Isla Socorro.

\section{REFERENCES}

Bautista-Romero, J., H. Reyes-Bonilla, D.B. Lluch-Cota \& S.E. Lluch-Cota. 1994. Aspectos generales sobre la fauna marina, p 247-275. In A. Ortega R. \& A. Castellanos V. (eds.). La Isla Socorro, Reserva de la Biosfera. Archipiélago de Revillagigedo, México. Publ. No. 8. CIBNor, S.C. La Paz, BCS, Mexico. 
Brusca, R.C. \& G.J. Brusca. 1990. Invertebrates. Sinauer, Sunderland, Massachussetts, USA. 922 p.

Castell, L.L. \& H.P.A. Sweatman. 1997. Predator-prey interactions among some intertidal gastropods on the Great Barrier Reef. J. Zool. 241: 145-159.

Chan, G.L. 1974. Report on biological observations of the Revillagigedos expeditions. NAUI Bio-marine Exploration Seminar. College of Main. Kentfield, California, USA. 41 p.

Devaraj, M. 1996. Sea-farming and conservation of molluscan resources of India. In J. Hylleberg \& $\mathrm{K}$. Ayyakkannu (eds). Proceedings of the Sixth Workshop of the Tropical Marine Mollusc Programme, Annamalai University, Chidambaram, India, 12-20 June 1995, 16: 71-78.

Dorairaj, K. \& R. Soundararajan. 1998. Status of molluscan resources of the Andaman Islands, p 106-115. In B. Gangwar, K. Chandra \& K. Andaman (eds). Island Ecosystem and Sustainable Development. Science Association, Port Blair, India.

Emerson, W.K. 1995. A Zoogeographic Summary of the Marine Mollusks of the Revillagigedo Island (tropical eastern Pacific Ocean). Festivus 27: 3-18.

Holguin, Q.O. 1991. Notas sobre especies de moluscos de interés comercial del Pacífico mexicano. Zool. Inf. 23: $19-41$.

Holguin, Q.O. 1994. Comunidades marinas bentónicas, p. 225-245. In A. Ortega R. \& A. Castellanos V. (eds.). La Isla Socorro, Reserva de la Biosfera, Archipiélago de Revillagigedo, México. Publ. No. 8. CIBNor, S.C. La Paz, BCS, Mexico.

Holguin, Q.O. \& E. Michel-Morfín. 2002. Distribution, density and length-weight relationship of Chiton articulatus Sowerby, 1832 (Mollusca-Polyplacophora) on Isla Socorro, Revillagigedo Archipelago, Mexico. J. Shellfish Res. 1: 239-241.
Holguin, Q.O., S. Mille-Pagaza \& A. Pérez-Chi. 1992. Resultado de las campañas de muestreo de 1991 para el estudio del bentos marino de isla Socorro, Revillagigedo, Colima, México. Zool. Inf. 24: 1-20.

Keen, M.A. 1971. Sea Shells of Tropical West America. Marine Mollusks from Baja California to Peru. Stanford, California, USA. 1065 p.

Kikutani, K., H. Ohba \& H. Yamakawa. 2002. Distribution and gut contents of the green snail Turbo marmoratus in Tokunoshima Island, Ryukyus (Southern Japan). J. Tokyo U. Fish. 88: 47-52.

Llinas-Gutierrez, J., D. Lluch \& A. Castellanos. 1993. Isla Socorro, Revillagigedo, p 520-534. In S.I. SalazarVallejo \& N.E. González (eds). Biodiversidad Marina y Costera de México. CONABIO-CIQRO, Mexico, DF, Mexico.

Michel-Morfín, J.E., E.A. Chávez \& L. González. 2002. Population structura, effort and dye yielding of the snail Plicopurpura pansa (Gould, 1853) in the Mexican Pacific. Ciencias Marinas 28: 357-368.

Mille-Pagaza, S., A. Pérez-Chi \& O. Holguin Q. 1994. Fauna malacológica bentónica del litoral de la Isla Socorro, Revillagigedo, México. Ciencias Marinas 20: 467-486.

Reyes-Bonilla, H. 1999. Additions to the summary of marine mollusks of the Islas Revillagigedo (Tropical Eastern Pacific Ocean, Mexico). Festivus 31: 31-40.

Strong, A.M. \& G.D. Hanna. 1930. Marine Mollusca of the Revillagigedo Islands, Mexico. Proc. Cal. Acad. Sci. Ser. 4. 19: 7-12.

Troyo-Diéguez, E. \& S. Pedrín. 1994. Aspectos hidro-fisiográficos y geológicos, p. 43-53. In A. Ortega R. \& A. Castellanos V. (eds.). La Isla Socorro, Reserva de la Biosfera, Archipiélago de Revillagigedo, México. Publ. No. 8. CIBNor, S.C. La Paz, BCS. Mexico. 